ORIGINAL ARTICLE

\title{
THE DIFFERENCE IN TBSA ESTIMATION BETWEEN EMERGENCY ROOM AND BURN UNIT IN SECOND TIER HOSPITAL IN CENTRAL JAKARTA
}

\author{
Aditya Wardhana*), Gammaditya A. Winarno, Sanjaya F. Tanjunga, \\ An'umillah Arini Zidna, \& Amani S. Augiani
}

Burn Unit, Division of Plastic Surgery, dr. Cipto Mangunkusumo National Hospital, Faculty of Medicine Universitas Indonesia. Jakarta, Indonesia.

\begin{abstract}
Introduction: Burn TBSA estimation is essential to administer fluid resuscitation. There are some methods, including Rule of 9 and Lund-Browder Chart. This study aims to identify the difference in TBSA estimation in Emergency Room \& Burn Unit.

Method: We conducted a retrospective cross-sectional study in design. The Inclusion criteria are patients admitted to the Jakarta Islamic Hospital Cempaka Putih (JIHCP) burn unit between April 2015-September 2018, acute patients who have complete demographic data, complete TBSA estimation in the emergency room (ER) and burn unit (BU). Exclusion criteria are patients who do not have complete demographical data and incomplete TBSA estimation between the emergency room and burn unit. The estimation of TBSA in the emergency room is done by General Practitioner, while in the burn unit is done by Plastic Surgeon.

Result: Of all 160 patients admitted, 142 patients are eligible in the inclusion criteria. Most of it was adult males with an average of 28.3 years old, suffering a grade II burn injury caused by scald. There is a higher mean of TBSA estimation in the Emergency room with 15.83 (SD 12.21) compared to the Burn Unit with 12.92 (SD 12.00). The maximum TBSA overestimation in ER reaches $24 \%$ TBSA than BU, while the minimum is $0.5 \%$. The Maximum TBSA underestimation in ER reaches $20 \%$ TBSA than BU, while the minimum underestimation is also $0.5 \%$. On average, ER overestimates about $6.7 \%$ TBSA and underestimates about $2.8 \%$ TBSA compared to BU.

Conclusion: The emergency room tends to overestimate the TBSA, with an almost $3 \%$ difference in mean $(p<0.05)$. There is an occurrence of a maximum $24 \%$ TBSA overestimation while averaging $6.7 \%$ TBSA.

Keyword: Burn Injury, TBSA Estimation.
\end{abstract}

\section{ABSTRAK}

Introduksi: Estimasi TBSA luka bakar sangat penting untuk melakukan resusitasi cairan. Ada beberapa metode, termasuk Rule of 9 dan Lund-Browder Chart. Penelitian ini bertujuan untuk mengetahui perbedaan estimasi TBSA di IGD \& Burn Unit.

Metode: Kami melakukan studi cross-sectional retrospektif. Kriteria inklusi adalah pasien yang dirawat di unit luka bakar Rumah Sakit Islam Jakarta Cempaka Putih antara April 2015-September 2018, pasien akut yang memiliki data demografi lengkap, estimasi TBSA lengkap di ruang gawat darurat (IGD) dan unit luka bakar. Kriteria eksklusi adalah pasien yang tidak memiliki data demografi lengkap dan estimasi TBSA yang tidak lengkap antara ruang gawat darurat dan unit luka bakar. Estimasi TBSA di IGD dilakukan oleh Dokter Umum, sedangkan di unit luka bakar dilakukan oleh Ahli Bedah Plastik.

Hasil: Dari 160 pasien yang dirawat, 142 pasien memenuhi kriteria inklusi. Sebagian besar adalah laki-laki dewasa dengan usia rata-rata 28,3 tahun menderita luka bakar derajat II akibat melepuh. Rata-rata estimasi TBSA di IGD 15.83 (SD 12.21) lebih tinggi dibandingkan dengan Burn Unit 12.92 (SD 12.00). Overestimasi TBSA maksimum di IGD mencapai $24 \%$ TBSA dibandingkan unit luka bakar, sedangkan minimum 0,5\%. Maksimum underestimasi TBSA di ER mencapai 20\% TBSA dibanding unit luka bakar, sedangkan underestimasi minimum rata-rata 0,5\%, IGD overestimasi sekitar 6,7\% TBSA dan underestimasi sekitar 2,8\% TBSA dibandingkan dengan unit luka bakar. Kesimpulan: UGD cenderung overestimasi TBSA, dengan perbedaan rata-rata hampir $3 \%(p<0,05)$. Terjadi overestimasi maksimum $24 \%$ TBSA sementara rata-rata 6,7\% TBSA.

Kata Kunci: Luka bakar, Estimasi TBSA

\section{Conflicts of Interest Statement:}

The author(s) listed in this manuscript declare the absence of any conflict of interest on the subject matter or materials discussed. Received: 0710 2020, Revised: 2711 2020, Accepted: 14032021 


\section{INTRODUCTION}

Burn TBSA estimation is essential to minimize burn time to admission gap, especially in burn patients with $>20 \%$ TBSA. Fluid resuscitation to prevent hypovolemic shock is a procedure that must be performed, primarily using Parkland Formula. ${ }^{1-3}$ Despite the importance of TBSA estimation to achieve excellent fluid resuscitation, TBSA's overestimation has been reported. ${ }^{4}$ Jakarta Islamic Hospital Cempaka Putih (JIHCP) is a second-tier private-owned hospital with a plastic surgeon supported by high care burn unit. While not all second-tier hospitals have this facility, JIHCP has a slight edge in managing the acute phase of burn injury. Length of stay (LOS) utterly affects many aspects of burn injury care, both for the patients and the provider..$^{5}$ Some studies suggest that the adequacy in burn resuscitation based on Parkland formula can reduce complications and length of stay (LOS). ${ }^{1-3,6}$

\section{METHOD}

We conducted a retrospective crosssectional study in design, collecting data from the medical record. The Inclusion criteria are patients admitted to the Jakarta Islamic Hospital Cempaka Putih (JIHCP) burn unit between April 2015-September 2018, acute patients who have complete demographic data, complete TBSA estimation in the emergency room (ER) and burn unit (BU). Exclusion criteria are patients who do not have complete demographical data and incomplete TBSA estimation between the emergency room and burn unit.

There are three most known methods of estimating TBSA: Rule of 9, Palmar Method, and Lund \& Browder Chart. ${ }^{5-7}$ The latter being the most accurate method to estimate, while the Rule of 9 might be the easiest to remember. However, further study is needed. There is a difference in TBSA estimation competence, wherein the ER is done by General Practitioner, while in BU is done by Plastic Surgeon. Statistical analysis and tabulation of the data using SPSS 20 for Mac.

\section{RESULTS}

\section{Demographic Profile}

Admission of patients between April 2015September 2018 reaching 160, and after reviewing the medical records, 142 patients are eligible in the inclusion criteria. Of all 142 patients included, $85(59.8 \%)$ were male, and $57(40.2 \%)$ were female, most of it is adult patients with $88(61.9 \%)$ patients, the mean age of 28.9 (SD 20.0), the youngest patient being seven months old, and the eldest being 78 years old. Demographic profiles were presented in Table 1, 2 and Figure $\mathbf{1}$.

The determination of burn grade is mostly by observation; therefore, it is subjective, depending on some factors, including experience. However, we found that the grading did not have any differences between ER \& BU. Most of it was grade II with $84(57.9 \%)$. The burn grade profile was presented in Table 2. Burn time to admission gap is mostly within 24 hours with 84 (59.1\%) (Figure 2). Most of the cause of burn injury in the population is scald with $48(33.8 \%)$, followed by gas explosion $46(25.4 \%)$ and fire $33(23.2 \%)$ being the most methods of injury. Figure 3 showed the proportion of burn causes.

The average length of stay of the population is 8.09 (SD 8.405) days treated in the burn unit, with a minimum of 0 days, meaning that the patients were discharged on their admission date. The maximum number of LOS reached 61 days (Table 3, Figure 4). Comparison between TBSA and LOS were also performed using Kolmogorov-Smirnov Test, with the most significant number of patients treated $<10$ days came from the $<10 \%$ TBSA group, meaning the less TBSA the population has, the fewer days they are likely to be treated in a burn unit $(\mathrm{p}<0.05)$.

Table 1. Age Category to Gender Profile

\begin{tabular}{llrrr}
\hline & & \multicolumn{2}{c}{ Gender } & \multirow{2}{*}{ Total } \\
\cline { 3 - 4 } & & Male & Female & \\
\hline Age & & & & \\
Category & Children & 26 & 20 & 46 \\
& Adult & 58 & 30 & 88 \\
& Elder & 1 & 7 & 8 \\
& Total & 85 & 57 & 142 \\
\hline
\end{tabular}


Table 2. Burn Grade Profile

\begin{tabular}{clcc}
\hline & & Frequency & Percent \\
\hline \multirow{4}{*}{ Grade } & I & 2 & 1.4 \\
& I-II & 10 & 6.9 \\
& II & 84 & 57.9 \\
& II-III & 38 & 26.2 \\
& III & 8 & 5.5 \\
& Total & 142 & 100.0 \\
\hline
\end{tabular}

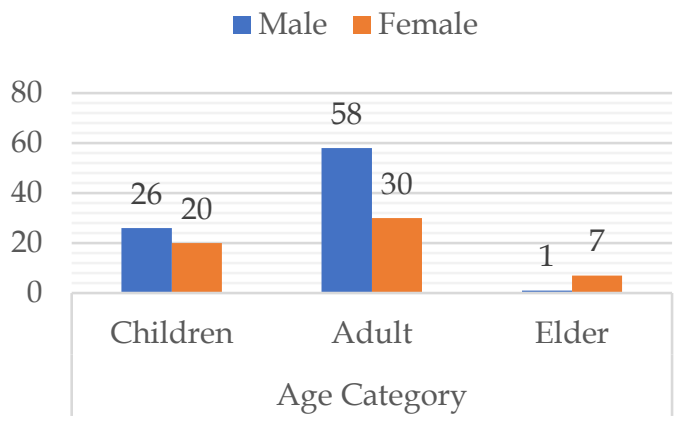

Figure 1. Age Category to Gender Profile

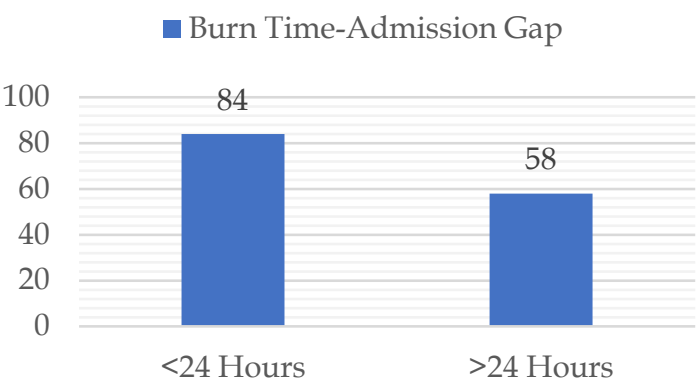

Figure 2. Burn Time-Admission Gap

Table 3. Length of Stay Frequency

Min Max Mean Std. Deviation

\begin{tabular}{lllll}
\hline LOS & 0 & 61 & 8.09 & 8.405 \\
\hline
\end{tabular}

\section{Bivariate Analysis}

Analyzing through the collected data shows a higher mean of TBSA estimation in the Emergency room with 15.83 (SD 12.21) compared to the Burn Unit with 12.92 (SD 12.00). TBSA overestimation ranging from $0.5-24 \%$, otherwise for underestimation, the range was within 0.5 $20 \%$. On average, ER overestimates about $6.7 \%$ TBSA and underestimates about 2.8\% TBSA compared to BU. There is a significant amount of difference in TBSA estimation with a tendency of overestimation by Emergency Department compared to Burn unit $(\mathrm{p}<0.05)$ with $68(47.8 \%)$ (Figure 5, Table 4 and 5).

The analysis shows us an overestimation tendency between ER to BU in JIHCP. It might be due to a difference in setting and goal in each department. ER tends to be more aggressive in
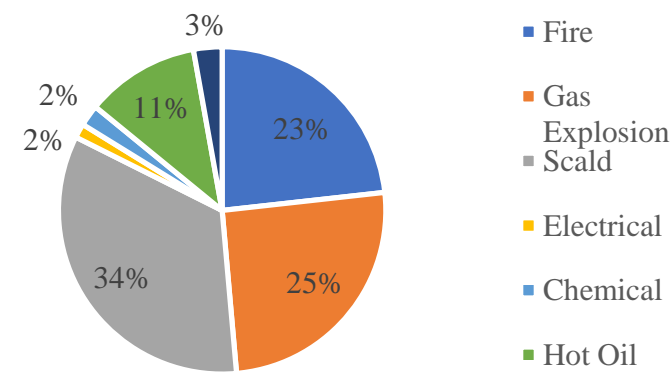

Figure 3. Cause of Burn Injury

$$
\text { - }<10 \text { Days } \quad \text { > } 10 \text { Days }
$$

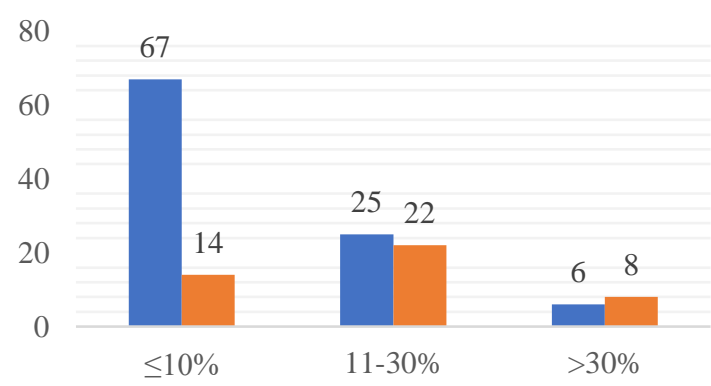

Figure 4. TBSA to LOS

managing the emergency and lifesaving situation that is more intense in terms of timing, so ER chief doctor might not want to waste more time estimating more accurate TBSA. However, it is vital to keep in mind that resuscitation of burn patients could affect the prognosis and adds complication, so accuracy improvement of TBSA estimation is crucial.

Table 4. Descriptive Analysis

\begin{tabular}{cccccc}
\hline & \multicolumn{5}{c}{ TBSA } \\
\cline { 2 - 6 } & Mean & Median & Max & Min & $\begin{array}{c}\text { Std } \\
\text { Dev }\end{array}$ \\
\hline ER & 15.83 & 12.00 & 58.50 & 0.50 & 12.21 \\
BU & 12.92 & 9.75 & 70.00 & 1.00 & 12.00 \\
\hline
\end{tabular}

*ER: Emergency Room

${ }^{*} B U:$ Burn Unit 
Table 5. Non-Parametric Test

\begin{tabular}{lll}
\hline & & $\mathrm{N}$ \\
\hline \multirow{4}{*}{ ER - BU } & Under Estimation & $26^{\mathrm{a}}$ \\
& Over Estimation & $68^{\mathrm{b}}$ \\
& Equal Estimation & $48^{\mathrm{c}}$ \\
& Total & 142 \\
\hline
\end{tabular}
a. $E R<B U$
b. $E R>B U$
c. $E R=B U$

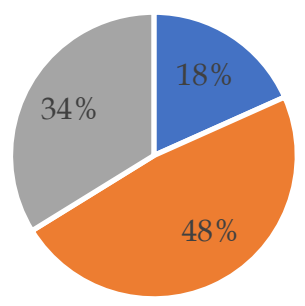

$$
\begin{aligned}
& \text { - Under } \\
& \text { Estimation } \\
& \text { - Over } \\
& \text { Estimation } \\
& \text { Equal } \\
& \text { Estimation }
\end{aligned}
$$

Figure 5. Percentage of TBSA Estimation

\section{DISCUSSION}

This study's main finding is to show a significant overestimation of TBSA between the ER and the BU. The study population showed a slightly higher case in males. This proportion was surprisingly supported by a recent systematic review assessing burn injury worldwide, that the mean ratio of men: women was 1.92:1.8 Adult is the predominant age group, with a range between seven months and 78 years old.

A grade II burn injury occurred in more than half of our patients. Scald is the primary cause of burn injury, followed by gas explosion and flame. These prevalent etiologies were similar to the previous study conducted in Canada, which stated that the most common causes were flame, scald, and chemical injury, respectively. ${ }^{2}$ Gas explosion-related burn injury also happened in Nigeria. ${ }^{9}$ Although the average LOS of the study population was eight days; the maximum LOS reached 61 days. The average number was lower compared to previous studies, which showed an average number of 27 days. 2

There is a significant tendency of TBSA overestimation by the ED compared to the $\mathrm{BU}$ $(p<0.05)$. This finding was in accordance with the previous studies that the inaccuracy of TBSA estimations had a tendency to overestimate, which leads to over-resuscitation and mortality as the final result.1,6 Although the trend of overestimation is multifactorial, we suggest some factors that may promote inaccurate estimation. The difference may be caused by an inevitable different measurement technique between the general practitioner and the plastic surgeon. Rule of nines is the most common technique used by the general practitioners in our hospital to measure TBSA vastly. This technique has been mentioned to have more tendency to overestimate. ${ }^{10}$ Besides, the burn erythema in the earlier phase may play a role to overestimate. The ER's primary goal is to save lives, that the patient care should be conducted as fast as possible. In contrast, the BU may have a longer time for patients' assessment to improve the accuracy.

There were some limitations found in this study. This study collects data through medical records retrospectively, and it might be helpful to conduct a further study that is done with the cohort so that information collection can be more comprehensive and complete. This research also did not assess why there is a difference in TBSA estimation between ER and BU, and it might be beneficial if primary data through ER doctors and BU doctors or other stakeholders are collected. Therefore, a correlation analysis could be performed.

\section{CONCLUSION}

The population's demographic data shows that most of it was adult males with an average of 28.3 years old. Most of the population suffers a grade II burn injury, caused by mostly scald, with an average LOS of 8.25 , where the less TBSA has less length of stay $(p<0.05)$. The emergency room tends to overestimate the TBSA, with an almost $3 \%$ difference in mean $(\mathrm{p}<0.05)$. There is an occurrence of a maximum 24\% TBSA overestimation while averaging $6.7 \%$ TBSA.

\footnotetext{
Correspondence regarding this article should be addressed to:

Aditya Wardhana. Burn Unit, Division of Plastic Surgery, Faculty of Medicine Universitas Indonesia, dr. Cipto Mangunkusumo National Hospital, Jakarta, Indonesia. EMail: aditya_wrdn@yahoo.com
} 


\section{REFERENCES}

1. Armstrong JR, Willand L, Gonzalez B, Sandhu J, Mosier MJ. Quantitative Analysis of Estimated Burn Size Accuracy for Transfer Patients. J Burn Care Res. 2017;38:e30-5.

2. Dolp R, Rehou S, McCann MR, Jeschke MG. Contributors to the length-of-stay trajectory in burn-injured patients. Burns [Internet]. 2018;44:2011-7. Available from: https://doi.org/10.1016/j.burns.2018.07.00 4

3. Face $S$, Dalton S. Consistency of total body surface area assessment in severe burns: Implications for practice. EMA - Emerg Med Australas. 2017;29:429-32.

4. Swords DS, Hadley ED, Swett KR, Pranikoff $\mathrm{T}$. Total body surface area overestimation at referring institutions in children transferred to a burn center. Am Surg. 2015;81:56-63.

5. Taylor SL, Sen S, Greenhalgh DG, Lawless MB, Curri T, Palmieri TL. Not all patients meet the 1 day per percent burn rule: $A$ simple method for predicting hospital length of stay in patients with burn. Burns [Internet]. 2017;43:282-9. Available from: http://dx.doi.org/10.1016/j.burns.2016.10. 021

6. Harish V, Raymond AP, Issler AC, Lajevardi SS, Chang LY, Maitz PKM, et al. accuracy of burn size estimation in patients transferred to adult Burn Units in Sydney, Australia: An audit of 698 patients. Burns [Internet]. 2015;41:91-9. Available from: http:/ / dx.doi.org/10.1016/j.burns.2014.05. 005

7. Redlarski G, Palkowski A, Krawczuk M. Body surface area formulae: An alarming ambiguity. Sci Rep [Internet]. 2016;6:1-8. Available from: http:/ /dx.doi.org/10.1038/srep27966

8. Redlarski G, Palkowski A, Krawczuk M. A systematic review of burn injuries in lowand middle-income countries: Epidemiology in the WHO-defined African Region. Sci Rep. 2016;6:1-8.

9. Belie O, Mofikoya BO, Fadeyibi IO, Ugburo AO, Buari A, Ugochukwu NN. Cooking gas explosions as cause of burns among patients admitted to a regional burn centre in Nigeria. Ann Burns Fire Disasters. 2020;33:62-8.
10. Wachtel TL, Berry CC, Wachtel EE, Frank HA. The inter-rater reliability of estimating the size of burns from various burn area chart drawings. Burns. 2000;26:156-70. 